\title{
Kecacingan pada Saluran Pencernaan Trenggiling Jawa (Manis javanica) dan Pengendaliannya
}

\author{
Riyan Wahyu Setiadi ${ }^{1}$, Risa Tiuria ${ }^{2}$, Chairun Nisa ${ }^{3 *}$ \\ ${ }^{1}$ Program Sarjana, Fakultas Kedokteran Hewan, Institut Pertanian Bogor \\ ${ }^{2}$ Departemen Ilmu Penyakit Hewan dan Kesehatan Masyarakat Veteriner, Fakultas Kedokteran Hewan, \\ Institut Pertanian Bogor \\ ${ }^{3}$ Departemen Anatomi, Fisiologi, dan Farmakologi, Fakultas Kedokteran Hewan, Institut Pertanian Bogor
}

ABSTRAK: Salah satu kendala dalam upaya konservasi Trenggiling jawa secara ex-situ adalah masalah penyakit, salah satunya kecacingan. Tujuan dari penelitian ini adalah untuk mengidentifikasi jenis cacing saluran pencernaan yang menginfeksi empat ekor Trenggiling jawa,serta mengetahui efektivitas dari anthelmintika yang diberikan. Identifikasi tipe telur, jenis larva, dan derajat infeksi kecacingan dilakukan dengan menggunakan teknik parasitologi. Hasil menunjukkan trenggiling yang dipelihara di kandang terinfeksi oleh cacing tipe Strongylid dan Ascarid. Seluruh trenggiling terinfeksi oleh cacing genus Strongylus. Infeksi ganda terjadi pada duaekortrenggiling, masing-masingoleh cacing genus Strongylus dan Trichostrongylus, serta cacing genus Strongylus dan Ascaris. Trenggiling terinfeksi cacing dengan derajat infeksi kategori ringan hingga sedang. Pemberian Albendazole dengan dosis $10 \mathrm{mg} / \mathrm{kgbb}$ setiap pekan mampu menurunkan jumlah telur cacing sebesar $100 \%$.

Kata kunci:

albendazole, ascarid, telur cacing, trenggiling jawa, strongylid

\section{- PENDAHULUAN}

Trenggiling jawa (Manis javanica) merupakan hewan langka dan dilindungi berdasarkan Undang-Undang (UU) Nomor 5 tahun 1990 dan Peraturan Pemerintah (PP) Nomor 7 tahun 1999, namun mengalami eksploitasi yang berlebihan sehingga dikhawatirkan akan mengalami kepunahan. International Union for the Conservation of Nature and Natural Resources (IUCN) telah memasukkan trenggiling dalam daftar red list kategori critically endangered species. Selain itu, Convention on International Trade in Endangered Species of Wild Fauna and Flora (CITES) terhitung sejak 2016 juga memasukkan trenggiling dalam daftar Appendix I. Diperlukan berbagai upaya untuk mencegah kepunahan satwa ini, salah satunya dengan usaha konservasi trenggiling baik secara in-situ maupun ex-situ. Salah satu upaya konservasi trenggiling secara ex-situ adalah melalui penangkaran. Hingga saat ini upaya konservasi ex-situ trenggiling masih sulit dilakukan, dikarenakan jenis pakan satwa ini yang sangat spesifik, yaitu semut dan rayap. Selain itu, informasi mengenai jenis-jenis penyakit yang dapat menjangkiti trenggiling pada pemeliharaan di dalam kandang juga masih sedikit dilaporkan. Salah satu penyakit yang dapat dialami oleh trenggiling adalah penyakit parasitik, baik ektoparasit maupun endoparasit. Kecacingan pada saluran pencernaan merupakan penyakit endoparasit yang paling sering diderita oleh mamalia, termasuk Trenggiling jawa (Manis javanica).

\section{- BAHAN DAN METODE}

Penelitian ini menggunakan tinja dari empat ekor Trenggiling jawa (A B, C, dan D) yang dipelihara di kandang, larutan pengapung, vermiculite, dan Albendazole. Metode yang digunakan berupa teknik sampling, flotasi sederhana, $M c$ Master, dan identifikasi larva infektif. Pengendalian kecacingan dilakukan dengan memberikan Albendazole dengan dosis $10 \mathrm{mg} / \mathrm{kgbb}$ yang dicampur bersama pakan (Bonal dan Gupta 2013). Pemberian obat dilakukan setiap pekan, hingga tidak ditemukan telur cacing pada saat pemeriksaan berikutnya.

\section{- HASIL DAN PEMBAHASAN}

Terdapat dua tipe telur yang teridentifikasi pada pemeriksaan flotasi sederhana, yaitu tipe Strongylid dan tipe Ascarid (Tabel 1). Berdasarkan hasil pemupukan pada tipe telur Strongylid, teridentifikasi dua jenis larva cacing, yaitu

\footnotetext{
Diterima : 21 Juli 2017

Direvisi : 8 Agustus 2017

Disetujui : 11 Agustus 2017
} 
Strongylus dan Trichostrongylus. Hasil pengamatan menunjukkan bahwa seluruh Trenggiling jawa terinfeksi oleh cacing genus strongylus. Infeksi ganda terjadi pada trenggiling C oleh genus Strongylus dan Trichostrongylus, dan trenggiling D oleh genus Strongylus dan Ascaris. Berdasarkan data yang tersaji pada (Tabel 1), Trenggiling jawa yang berada di kandang terinfeksi Nematoda parasitik dengan derajat infeksi yang bervariasi.

Tabel 1 Jumlah telur tiap gram tinja (TTGT) setiap jenis telur cacing sebelum pengobatan

\begin{tabular}{|c|c|c|}
\hline \multirow{2}{*}{ Trenggiling } & \multicolumn{2}{|c|}{ TTGT (Telur tiap gram tinja) } \\
\cline { 2 - 3 } & Strogylid & Strongylid dan Ascarid \\
\hline A & 450 & - \\
B & 450 & - \\
C & 1650 & - \\
D & - & 2100 \\
\hline
\end{tabular}

Menurut Thienpont et al. (1995), hewan yang terinfeksi dengan jumlah TTGT 1-499 termasuk kategori infeksi ringan, jumlah TTGT 500-5000 kategori infeksi sedang, dan jumlah TTGT > 5000 termasuk kategori infeksi berat. Derajat infeksi pada Trenggiling jawa masih belum diketahui, maka sebagai acuan digunakan kisaran jumlah TTGT tersebut, yang sangat erat kaitannya dengan gejala klinis yang ditimbulkan. Trenggiling A dan trenggiling B terinfeksi oleh cacing genus Strongylus dengan derajat infeksi ringan, sehingga tidak menunjukkan gejala klinis. Gejala klinis muncul pada trenggiling $\mathrm{C}$ dan trenggiling D. Pengamatan pada kondisi tinja menunjukkan bahwa Trenggiling $\mathrm{C}$ mengalami melena, sedangkan pengamatan pada kondisi fisik dan hematologi menunjukkan bahwa trenggiling D mengalami kahexia, diare kronis, lethargi, dan anemia. Noble dan Noble (1989) menyebutkan bahwa, cacing genus Trichostrongylus merupakan cacing penyebab diare, anemia, dan pendarahan mukosa, hingga menyebabkan terjadinya melena. Zalizar et al (2006) juga mengungkapkan bahwa, infeksi cacing tipe telur Ascarid dengan dosis berat (8000 telur infektif) dapat menyebabkan terjadinya degenerasi dan nekrosis pada sel-sel epitel usus halus, dan menyebabkan penurunan luas permukaan vili usus sebesar $20 \%$.

Pemberian Albendazole dari minggu 0 terbukti berpengaruh terhadap derajat infeksi kecacingan. Hasil pemeriksaan menunjukkan bahwa pada minggu ke- 8 trenggiling A dan B terbebas dari infeksi kecacingan, atau dalam pemeriksaan memiliki nilai TTGT $=0$, Sementara trenggiling $\mathrm{C}$ dan D memiliki nilai TTGT = 0 pada minggu ke-9 (Gambar 1). Hasil pemeriksaan tersebut sejalan dengan pendapat Jarvinen (2005) bahwa penggunaan Albendazole secara oral dapat mengurangi $100 \%$ telur tipe Strongylid.

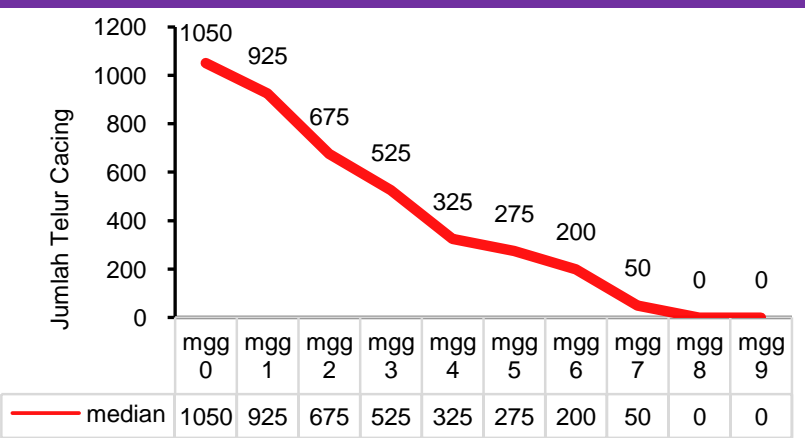

*Keterangan : mgg = minggu

Gambar 1 Grafik median jumlah TTGT (telur tiap gram tinja) setiap pekan pascapengobatan

\section{- SIMPULAN}

Identifikasi menunjukkan seluruh trenggiling terinfeksi oleh cacing genus Strongylus. Infeksi ganda terjadi pada trenggiling $\mathrm{C}$ oleh cacing genus Strongylus dan Trichostrongylus, dan trenggiling D oleh cacing genus Strongylus dan Ascaris. Secara keseluruhan, trenggiling mengalami kecacingan dengan derajat infeksi ringan hingga sedang. Pengobatan menggunakan albendazole $10 \mathrm{mg} / \mathrm{kgbb}$ secara periodik tiap minggu, terbukti mampu menghilangkan telur cacing sebesar $100 \%$.

\section{- INFORMASI PENULIS}

Penulis untuk Korespondensi

chnisa@yahoo.com

Persetujuan Penulis

Semua penulis menyetujui naskah akhir ini untuk dipublikasikan.

\section{- UCAPAN TERIMA KASIH}

Penulis mengucapkan terima kasih kepada Laboratorium Helmintologi Departemen IPHK FKH IPB, Pusat Studi Biofarmaka TropikaLPPM IPB, Lembaga Ilmu Pengetahuan Indonesia (LIPI), dan Ditjen PHKA Kementerian Lingkungan Hidup dan Kehutanan.

\section{- PUSTAKA ACUAN}

Bonal BS, Gupta BK. 2013. Rescue and Rehabilitation Efforts in Saving Wildlife. In Acharjyo LN and Panda S (eds). Indian Zoo Year Book. Vol VII. Indian Zoo Directors. Association and Central Zoo Authority, New Delhi: pp 1-5.

Jarvinen JA. 2005. Anthelmintics for Use in Camelids. Iowa State University: USA.

Noble ER, Noble GA. 1989. Parasitologi, Biologi Parasit Hewan Ed ke-5. Terjemahan oleh Wardianto. Gadjah Mada Universitas Press. Yogyakarta

Thienpont D, Rochette F, Vanparus OFJ. 1995. Diagnosing Helminthiasis Through Coprological Examination. America (US): Appleton-Century-Crofts.

Zalizar L, Satrija F, Tiuria R, Astuti DA. 2006. Dampak infeksi Ascaridia galli terhadap gambaran histopatologi dan luas permukaan vili usus serta penurunan bobot hidup starter. J Ilmu Ternak dan Veteriner 11(3): 215-222. 